Original Research Paper

\title{
Impacts of Large-Scale Stormwater Green Infrastructure Implementation and Climate Variability on Receiving Water Response in the Salt Lake City Area
}

\author{
Chris York, Erfan Goharian and Steven J. Burian \\ Department of Civil and Environmental Engineering, University of Utah, Salt Lake City, USA
}

\author{
Article history \\ Received: 28-02-2015 \\ Revised: 24-07-2015 \\ Accepted: 19-09-2015 \\ Corresponding Author: \\ Chris York \\ Department of Civil and \\ Environmental Engineering, \\ University of Utah, Salt Lake City, \\ USA \\ Email: chris.york@utah.edu
}

\begin{abstract}
This study evaluated impacts of Green Infrastructure (GI) as a stormwater management practice on return flows and the further Implications of climate variability. The goal was to create a model to explore the impacts that bioretention and Rainwater Harvesting (RWH) representing GI had using goldsim and Stormwater Management Modeling (SWMM) software. The software was used to represent impacts that climate variability individually and combined, may have on downstream stakeholders and receiving water systems in Salt Lake city, Utah, USA. Primary stakeholders included downstream water rights users, Farmington Bay waterfowl management area and the migratory birds that rely on Farmington Bay and the advocates that represent them. The steps to reach this goal were broken down incrementally to: (1) Characterize daily inflows to Farmington Bay, (2) Provide daily inflows from natural and urban runoff to the Jordan river, (3) Create a daily water balance model of Farmington Bay, (4) Demonstrate the model with and without stormwater GI and climate variability scenarios and (5) Determine trends of inflow to the Jordan River, duck clubs and Farmington Bay under various scenarios. The simulation results demonstrated that bioretention and RWH individually and combined had minimal impact on downstream water users, Jordan River flows and ultimately Farmington Bay water levels. Bioretention reduced the flow in the Jordan River minimally, with reductions primarily during peak flow. RWH actually kept more water in the natural system on average because less water was needed from the water treatment facilities when outdoor irrigation was supplemented with rainwater. The user reliability did not differ for any of the bioretention and RWH scenarios. The climate variability scenario had the greatest impact to Jordan River flows, Farmington Bay water levels and user reliability. When analyzed without GI implementation, the climate variability induced reduction in tributary flows and precipitation led to an average decrease of $11 \%$ in the Jordan River streamflow when compared to average baseline scenario over a 25 year simulation. The user reliability decreased by $5 \%$ and most importantly there was found to be an average of $36 \%$ decrease in the water levels in Farmington Bay. The resultant of the decrease in Farmington Bay water level is a loss of up to 61 square kilometers $(15,000$ acres $)$ of open bay that would impact bird habitat, brine shrimp grounds, recreationalists, bird watchers, hunters and more. For this case study the implications of climate variability on the water system are much greater than implementing GI.
\end{abstract}

Keywords: Green Infrastructure, Climate Variability, Bioretention, Rainwater Harvesting 


\section{Introduction}

Utah is a water-limited region. There are competing interests for water, ranging from government and non-government organizations, residents, private industry, indigenous populations and others. Amplifying the problem is a lack of understanding of how changes to contributing watershed areas, water management and climate could impact flows in waterways and water availability for supply and ecosystem services. Such uncertainties are important in many cities in the United States that are trying to adopt GI practices and adapt to a variable climate. Two specific areas of uncertainty are the impacts of widespread GI installation in urban watersheds and climate variability on flows in waterways and water availability in the Salt Lake City metropolitan area.

GI is a practice associated with Low-Impact Development (LID) principles that have become increasingly popular in stormwater management. LID practices seek to reduce the negative impacts that imperviousness and urbanization have on the environment (Dietz, 2007). GI is a stormwater control that mimics natural processes to retain stormwater (EPA, 2010a). Studies on effects of GI on the water cycle have found a wide range of possible outcomes (Burian and Pomeroy, 2010). There are documented improvements in water quality and reductions in stormwater runoff that have important management benefits. In the U.S., implementing 189 liter (50-gallon) rain barrels in a watershed was shown to have the potential to reduce stormwater runoff by $12 \%$ (Steffen et al., 2013). Additionally, it was determined that implementing a watershed-scale RWH plan could reduce stormwater volume 11-13\% (Walsh et al., 2014). Bioretention has not been explored extensively at the watershed-scale. Recognizing this fact, Barich (2014) explored a case study of the Ballona Creek Watershed in the Los Angeles Area. It was determined that implementing bioretention cells in the watershed were effective in reducing $20-30 \%$ of stormwater runoff (Barich, 2014). In the North Farm Creek Watershed near Peoria, Illinois, a study showed that implementing bioretention and rain gardens on $50 \%$ of the urban area would result in a reduction of runoff volume equaling 25\% (TT, 2012).

Projections of climate variability impacts on water resources suggest increased evapotranspiration, increased growing season and ultimately a decrease in the water balance by a potential $30 \%$ (UDWR, 2008). At the regional scale, climate impact studies of streamflow in the Colorado River have indicated possible future flow decrease ranging from 10-25\%, with an average of 19\% (Seager et al., 2007; Nash and Gleick, 1993; Milly et al., 2005; McCabe and Wolock, 2007). In Salt Lake City, the projection of potential future climate variability shows increases in vulnerability and reduction in reliability of the water supply system over next 50 years (Goharian et al., 2015).

Although studies of GI and climate variability impacts on stormwater runoff and streamflow have been conducted independently in other locations, there is no evidence in the literature of a study of them individually and combined in mountain West climates in the U.S. The study presented herein seeks to quantify the impacts of GI on receiving water response and system reliability in Salt Lake City and in a unique way explore the influence of uncertain climate variability on the impacts. This research is guided by the overarching question of how watershed management practices (e.g., GI) and climate variability will impact the reliability of water supply and receiving water response. Of particular interest is to determine if implementing GI in water scarce regions could lead to reduced flows, lowered receiving water levels and in turn reduce water system reliability. This also can give insight into whether GI will amplify or mitigate climate variability impacts when implemented on a large scale in a water limited city. The proceeding sections document the methods, model, scenarios and results of this study.

\section{Methods}

The study of GI implementation and climate variability impacts on receiving water response and water supply reliability was conducted using a case study of the Jordan River-Farmington Bay system in the Salt Lake City Region. A system dynamics model of the Jordan River watershed, the Jordan River and Farmington Bay was created to represent the natural processes, human management and interactions. Simulations were executed to represent implementation of RWH and bioretention individually and combined and also with and without climate variability. The land usage and type was not altered for this study except in replacement of pervious area with impervious area with GI characteristics. This factorial experiment was used to determine the relative individual and combined effect on flows in the Jordan River, reliability of water deliveries to water users at the downstream end of the Jordan River and resulting water levels in Farmington Bay. The model was demonstrated under the most conservative scenario in which shallow groundwater recharge from stormwater was not returning to the Jordan River. This means that while GI has been shown to aid in replenishing groundwater supplies, this model does not represent that. Additionally, population increase was not considered in this study. Both are reasonable assumptions as the recharge from 
stormwater runoff to water supply aquifers is expected to be minimal because most of the stormwater infiltration will be captured in perched aquifers and used by vegetation. Additionally population growth is expected to continue to be high, but to be modest in the study area watersheds.

\section{Case Study}

Farmington Bay is located approximately $19 \mathrm{~km}$ North West of downtown Salt Lake City. It is the Southeastern arm of the Great Salt Lake and the terminus of the majority of flow through the Jordan River, which collects flow from streams in the Salt Lake Valley and drainages from the Salt Lake City metropolitan area. The eastern boundary of Farmington Bay is Davis County and the Western boundary is Antelope Island, the largest island in the Great Salt Lake (Fig. 1).
Farmington Bay is shallow, with a maximum depth of roughly two and a half meters (UUHS, 2013). The mean depth is approximated to be just above one and a half feet (UUHS, 2013). The average water surface elevation was determined to be 1,280 m (4,200 feet) above mean sea level (EPA, 2010b). Farmington Bay has many inflows including the Jordan River, tributaries from Davis County, groundwater, among others. A fraction of the input is from surface flows, which means that the inflow is susceptible to urbanization and management changes in those watersheds. Additionally, the evaporation and overall level of the Bay could be sensitive to future climate conditions. With the shallow water depths of Farmington Bay, the natural system could see significant disturbances from climate variability and/or GI implementation.

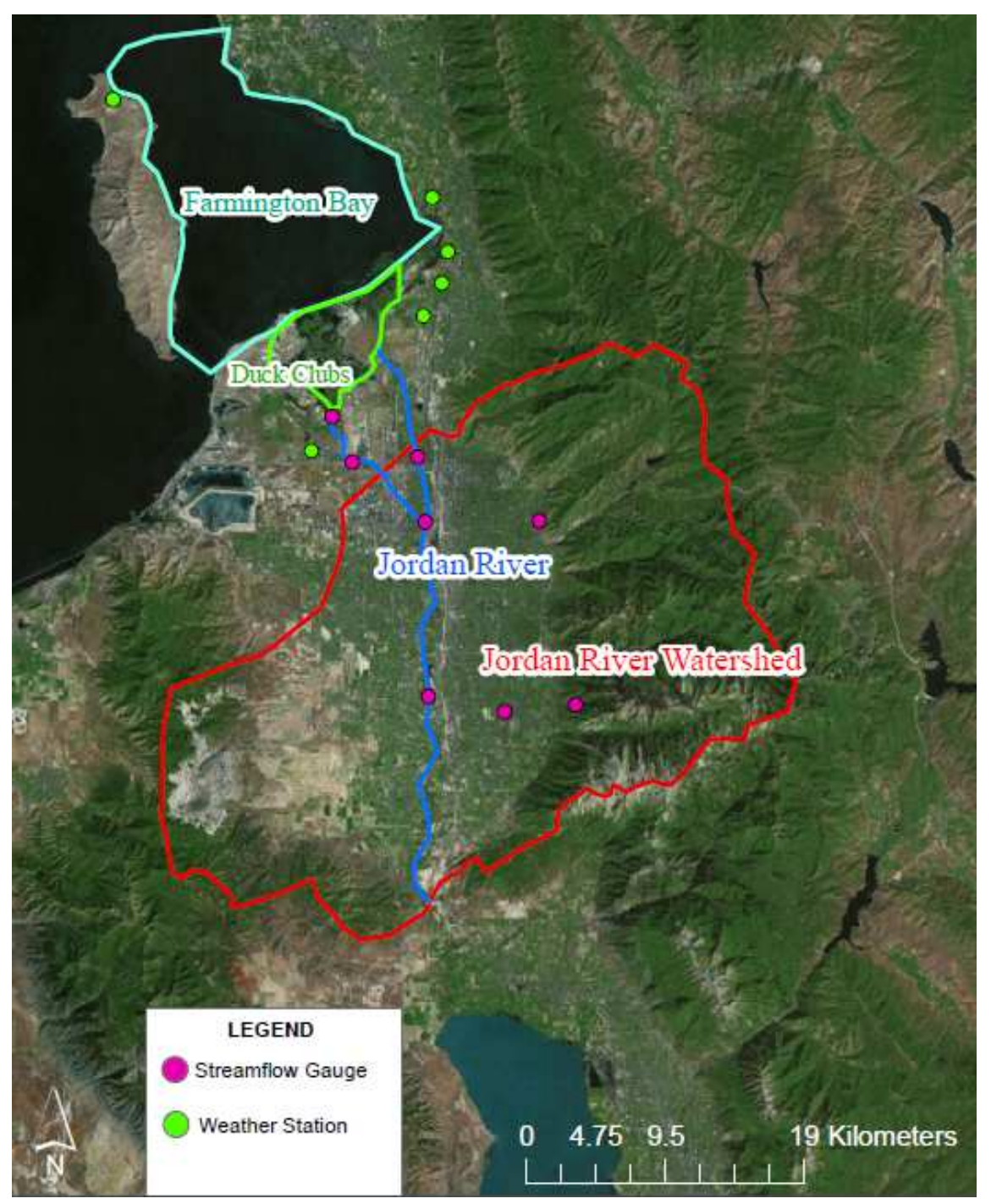

Fig. 1. Overview of study area 
The sensitivity in streamflow not only affects Farmington Bay and the natural system, but humans as well. The impact to the human system was quantified by impacts to the water rights users, specifically the Farmington Bay Duck Clubs. This was explored by understanding how water is distributed to water users along the Jordan River, which entailed characterizing the Lower Jordan River, quantifying water rights and recognizing how water rights are fulfilled. Generally speaking, the higher priority rights that were established first are the upstream irrigation users. Some of the duck clubs have different priority dates ranging from the late 1800 's to early 1900's. This means that the Farmington Bay Duck Clubs are the last users on the Jordan River System, but are not last in priority. Since the Jordan River drainage is over-appropriated, lower water years can leave water rights holders without a full allocation of water. The water rights system was incorporated into the model to quantify impacts to users under normal conditions and conditions when GI and climate variability are present.

Reliability of the water system was defined using a combination of the water rights filed with the Utah Division of Water Rights and personal conversations with the distribution engineer and river commissioner for the Lower Jordan River. The flows discussed pertaining to duck club water rights represent the needs of all the clubs as they were aggregated together due to their sequential nature and agreements that date back decades. To fulfill the needs of the Farmington Bay Duck Clubs, the flows that are conveyed to the duck clubs were determined by splitting them into time periods. The first period is January 15 to March 15 , when no water is necessary as they are releasing water to control freeze-thaw. Starting from March 15 to the end of March the clubs receive a flow of 6,120 cubic meters per hour $\left(\mathrm{m}^{3} / \mathrm{h}\right)(60$ cubic feet per second (cfs)) to fill their ponds. From March 31 to August 15 a baseflow of $4080 \mathrm{~m}^{3} / \mathrm{h}$ (40 cfs) is requested to maintain water quality and allow the duck clubs to grow nesting grounds and propagate wildlife. During this time the duck clubs will also perform invasive species control and may release water to do so. During the end of August there is a two week window to refill their ponds, determined to be from August 15 to August 31 , when $6,120 \mathrm{~m}^{3} / \mathrm{h}(60 \mathrm{cfs})$ is desired. From the end of August to January 15 a baseflow of 4,080 $\mathrm{m}^{3} / \mathrm{h}$ (40 cfs) is again desired to maintain water quality and prevent the ponds from freezing. If the streamflow amounts are unable to meet these thresholds, the system is considered to be in a failure state (and thus not reliable).

\section{Model}

The model was created in GoldSim with the goal of capturing precipitation, runoff, GI and climate factors that affect the receiving waterways on a daily scale. GoldSim is a Monte-Carlo simulation based modeling software (http://www.goldsim.com/Home/) and was selected because of its versatility in modeling water supply and hydrologic processes, as well as the ability to integrate multiple components into one model. The model was comprised of two linked sub-models, one focusing on the Jordan River and the other on Farmington Bay's water budget.

The Jordan River portion encompasses the urban areas and creeks that supply water to the Salt Lake Valley, as well as return flows from Utah Lake to the Jordan River. The boundary of the model is the Jordan River to the West, 9000 South to the south, the extent of the urban reach to the east and the Jordan River prior to terminating into Farmington Bay to the North. At 9000 South, Salt Lake County maintains a streamflow gauge which is used in the model to represent the inflow from Utah Lake, irrigation return flows and runoff from parts of the West and Oquirrh Mountains. To the East, observed streamflows from the major Wasatch Mountain creeks represented the inflows and boundary of this portion of the model. The aforementioned creeks are City, Emigration, Parleys, Mill, Big Cottonwood and Little Cottonwood Creeks.

To represent stormwater runoff, the U.S. Environmental Protection Agency Storm Water Management Model (SWMM) was incorporated into the GoldSim modeling framework to provide stormwater flows to the Jordan River model. However, there are always challenges with temporal and spatial scales, transferring inputs and outputs among different models, formatting of inputs and outputs and other challenges to overcome linking models. In order to model the stormwater in the system, an existing calibrated SWMM model for the study area was linked to the systems model in GoldSim. To link GoldSim and SWMM, the external Dynamic Link Library (DLL) of SWMM is linked to GoldSim to transfer data in each time step. SWMM was connected using a DLL created in $\mathrm{C}++$. In each time step, rainfall and other characteristics of subbasins transfer from GoldSim to SWMM, the model runs and the output (runoff) are transferred back to GoldSim. Details of linking GoldSim and SWMM can be found in Goharian and Burian (2014). All of the data used to determine the model parameters was gathered from the Salt Lake County Water Quality Stewardship Plan (WaQSP) and GIS database (SLCWRP/RSC, 2009). Soils data were originally 
downloaded from the National Resource Conservation Service (NRCS) Soil Data Mart. Existing land use data were originally developed for the use in the WaQSP report. Watershed boundaries were delineated by Salt Lake County and were based on topography in the mountains and stormwater collection systems in the valley. The Curve Number method was used to estimate infiltration for the model. The Curve Number was calculated using land use and soil type data provided by Salt Lake County. The GIS data available by Salt Lake County consisted of the area for each land use type and associated Hydrologic Soil Group (HSG) within each sub-watershed. Actual rainfall data was used for the precipitation in the model. The United States Geological Survey (USGS) weather station precipitation amounts at the Salt Lake City International Airport, station ID 427598, was downloaded and searched for an appropriate rainstorm that had a reasonable volume of rainfall in the watershed.

The SWMM model was divided into nine subcatchments representing the major urban areas that comprise Salt Lake City. GI was incorporated into each sub-catchment. According to the SWMM manual, the approach to represent GI selected used sub-area routing (USEPA, 2010). Impervious surfaces were replaced with pervious surfaces with parameters representing bioretention. Rain barrels were modeled as a single reservoir with a capacity equal to the volume of rain barrels in each respective sub-catchment. As the rain barrel capacity filled, it was applied to outdoor demand. If the rain barrel capacity filled, an over-drain directed the overflow to the storm drain. The rain barrels were primarily operated during the irrigation season, but small demands were met in the winter time. Winter was the primary season in which the over-drain was employed and water was sent to the storm drain.

The water demand and population from each subcatchment controls how much water flows through the streams to the water treatment facilities and ultimately each sub-catchment. Municipal water demands were divided into indoor and outdoor demands, which control the ultimate fate of the water (into sewer or not). Excess water flows from the natural streams, effluent from wastewater treatment facilities and discharge from storm drains are all directed to the Jordan River. The flows from the Jordan River, after management actions have used or diverted water, are directed in the model to Farmington Bay.

The water budget of Farmington Bay is modeled to simulate the impacts of upstream actions on Farmington Bay water levels. This included modeling the duck clubs of Farmington Bay to determine user reliability and quantify impacts to the human system. The model calculated the mass balance and change in storage in Farmington Bay, based on the inputs and outflows at each time step (one day). The inputs included in the model were surface runoff, precipitation, effluent from wastewater treatment facilities, return flows from irrigation and net groundwater flow. Surface runoff was comprised of inflows from the Jordan River, Antelope Island Drainage to the West and Davis County tributaries to the east. The surface streams and canals had maximum flows they were capable of handling without damaging or flooding the canal. These values were determined through historical data and conversations with the river commissioner and distribution engineer for the Lower Jordan River. Excess water, especially after a storm and during spring runoff is sent to the Goggin Drain which terminates into Gilbert Bay, the main body of the Great Salt Lake (GSL). The Goggin Drain is a deep channel designed to handle high flows when the goal is to get rid of excess water from the system. The outputs included in the model were net outflow to the GSL through the Antelope Island causeway culvert and evapotranspiration. In this study, seepage flows through the dikes separating the Farmington Bay from GSL were assumed negligible.

The complex behavior of flow through the bridge at the Antelope Island causeway makes modeling challenging because the physical behavior is affected by various parameters including brine density, water surface elevation of Farmington Bay and GSL, wind speed, wind direction and physical properties of the connection. For this project, monitored bi-directional flow time series from the USGS sensor at the Antelope Island Causeway was used to check the water balance in the Bay. However, the flows through the causeway can change with depth due to brine density and the flows can vary and even switch direction throughout the day, which is not captured by the gauge. In order to capture the uncertainty of bi-directional flow in causeway, a normal distribution was fitted to the observed flow and water level. A Monte Carlo simulation was then run for each scenario with 1000 separate and independent results produced, each representing a possible future for the system. The mean of all the possible simulations is used in this study.

Simulations were executed using data collected between October 2003 and October 2010. There are multiple reasons why these years were exclusively selected. First, this was a period when the necessary data was available. This included streamflow and precipitation. Secondly, the average precipitation from 2003 to 2010 in Salt Lake City, according to the National Weather Service, was 391 millimeters (15.4 inches). In comparison, the 30 year average from 1984 to 2014 was 396 millimeters (15.6 inches), which means that these years are representative of average conditions. 
In this study, simulations were conducted to mimic a future time period. The simulations were run as if the GI and climate variability were in effect. For the changes to the natural system or Farmington Bay, a longer time period was desired to accurately project trends. To do this, the same time period was repeated for data input parameters until a total period of 25 years was available for analysis.

\section{Calibration/Validation}

There is no historical data for the Farmington Bay water surface elevation and water depth. Therefore, this data cannot be used to calibrate the model. However, other methods were employed to validate the Farmington Bay model. The most basic check of the model is the water balance error, which was found to be less than 0.001. In this study, Farmington Bay is modeled as a reservoir element in GoldSim. The approach used in this model accounts for all flows that occur on and off the scheduled time step change. If the flows are not balanced, a runtime error is issued. The mass balance includes the functions that account for flows and volumes to ensure there is mass balance. If the mass balance error exceeds specified criteria, then an error message is displayed and the simulation is interrupted.

The second step to validate the model was comparing the inflows and outflows from other studies. Each module of the model was compared with historical data (Table 1). The values in Table 1 show adequate match of simulated and observed values for the range of metrics compared. Groundwater results were compared to four different studies which had a range of groundwater contribution to Farmington Bay from 16,000 to 58,000 acre-feet (Carter, 1971; Waddell and Fields, 1977).

Chadwick et al. (1986; Bishop et al., 2009). The average annual precipitation was collected from historical data and compared to direct precipitation findings from Bishop et al. (2009), with both averaging about 14 inches of rain per year. Evaporation from Farmington Bay was determined to be nearly 48 inches from this study. In, comparison, two independent studies found evaporation values of 50 and 52 inches (Waddell and Fields 1977; Chadwick et al., 1986). The final comparison was between surface inflows from this study and Chadwick et al. (1986), which showed similar results. Additionally, the simulated water level of Farmington Bay was assessed. When compared to the inflows and outflows, the water level responded as expected. The water level rises appropriately in response to increasing inflows and vice versa.

Finally, an optimization routine was executed within GoldSim to calibrate the Jordan River flows. This optimization sought to maximize the coefficient of determination (R-squared value). Monthly correction factors were calculated based on the optimization and applied to the model. The first five years were used for the calibration with the last two years being used for validation (Fig. 2).

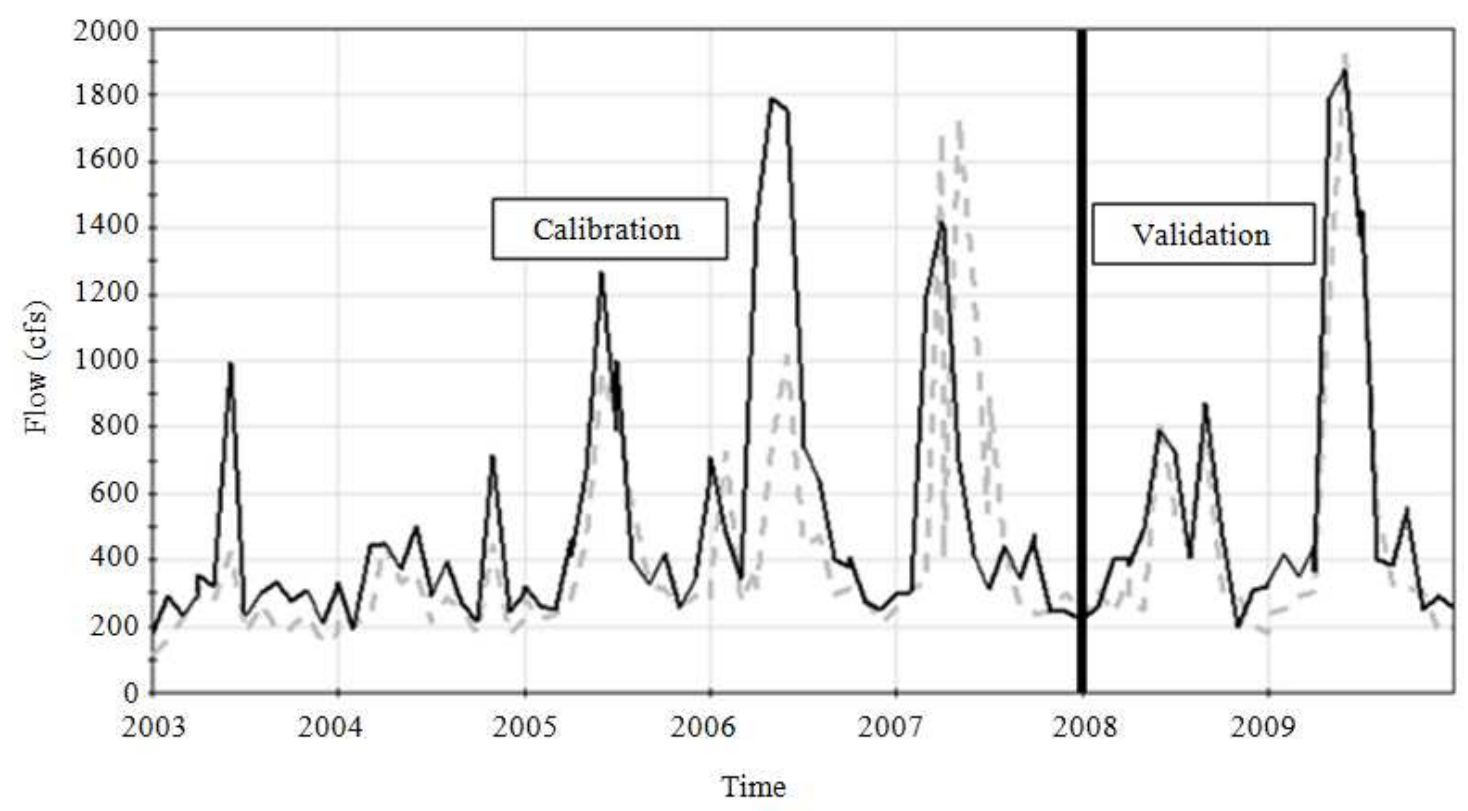

- - Calibrated model flows $\quad$ Jordan River gauge data

Fig. 2. Jordan River flows for calibration and validation period 
Table 1. Comparison of inputs used in this study versus findings of previous studies Groundwater

\begin{tabular}{|c|c|c|c|}
\hline & \multicolumn{3}{|l|}{ Groundwater } \\
\hline & Literature review & & This study \\
\hline Carter (1971) & $\begin{array}{l}\text { Annual groundwater contribution to } \\
\text { Farmington Bay }\end{array}$ & 58,000 acre-feet & $\begin{array}{l}4000 \text { acre-feet }+16,000 \text { acre-feet } \\
\text { via wetlands }\end{array}$ \\
\hline Waddell and Fields (1977) & Groundwater inflow in Farmington Bay & 27,600 acre-feet & \\
\hline Chadwick et al. (1986) & Groundwater inflow to Farmington Bay & 20,000 acre-feet & \\
\hline Bishop et al. (2009) & $\begin{array}{l}\text { Annual groundwater inflow to the wetlands } \\
\text { along the eastern shoreline of Farmington } \\
\text { Bay in Davis County }\end{array}$ & 16,000 acre-feet & \\
\hline Precipitation & & & \\
\hline $\begin{array}{l}\text { Bagley et al. (1964) } \\
\text { Evaporation }\end{array}$ & Normal annual precipitation on Farmington Bay & 14 inches & 13.86 inches \\
\hline Waddell and Fields (1977) & $\begin{array}{l}\text { Annual evaporation rate at Farmington } \\
\text { Bay Wildlife Management Area }\end{array}$ & 50.2 inches & $\begin{array}{l}38.78 \text { from surface water }+8.64 \\
\text { from Duck Ponds }=47.42 \text { inches }\end{array}$ \\
\hline $\begin{array}{l}\text { Chadwick et al. (1986) } \\
\text { Surface runoff }\end{array}$ & Annual freshwater evaporation for Farmington Bay & 52 inches & \\
\hline Chadwick et al. (1986) & $\begin{array}{l}\text { Surplus Canal to Farmington Bay } \\
\text { North and Central Davis treatment plants }\end{array}$ & $\begin{array}{l}83,000 \text { acre-feet } \\
25.16 \mathrm{cfs}\end{array}$ & $\begin{array}{l}85,407 \text { acre-feet } \\
25 \mathrm{cfs}\end{array}$ \\
\hline
\end{tabular}

Table 2. Scenarios included in the analysis

\begin{tabular}{lll}
\multicolumn{2}{l}{ Table 2. Scenarios included in the analysis } \\
\hline Scenario number & Scenario & Description \\
\hline 1 & Baseline & Representation of observed conditions \\
2 & Climate Variability 20\% & $20 \%$ streamflow and precipitation reduction due to future altered climate \\
3 & Full Bioretention & 1800 acres of bioretention implemented into the 70,000 acre site \\
4 & $100 \%$ RWH & All single-family homes Salt Lake City and surrounding suburbs \\
& & implement 200 gallon rain barrels \\
6 & $100 \%$ RWH and Full Bioretention & Implementation of both scenario 3 and scenario 4 \\
& Climate Variability 20\%, Full & Implementation of scenario 2, scenario 3 and scenario 4 \\
\hline
\end{tabular}

\section{Simulation Scenarios}

Following model testing and validation, six scenarios were devised to focus primarily on GI implementation and secondarily climate variability impacts on Farmington Bay and downstream water users (Table 2).

\section{Rainwater Harvesting}

Rain barrels were modeled as part of the urban sub catchments with water being applied to meet the outdoor demand. The water was released to the pervious portions of that drainage and was then susceptible to infiltration and evaporation. In case of over flow, the water was sent to adjacent pervious areas and the storm drain. To determine the number of rain barrels that Salt Lake County could implement, United State Census data for the cities of interest were gathered. This number defined the quantity of rain barrels represented in the model. The cities included in the study were Murray, Cottonwood Heights, Salt Lake City, Sandy, Millcreek, Midvale and Taylorsville. For the seven cities represented, there was a maximum of 128,500 single-family homes determined as able to implement rain barrels.

Currently, the maximum amount of water a person may collect without registering with the Utah Division of Water Rights is 757 liters (200 gallons). A person may collect up to 9464 liters (2,500 gallons) and store underground if they register with the Division of
Water Rights. A sensitivity study conducted with 757, $3,785,9,464$ liter $(200,1,000$ and 2,500 gallon) rain barrels implemented showed that 757 to 3,785 liter (200-1,000 gallon) barrels were most effective for stormwater management. This size captured runoff from most storm events and typically emptied by the time the next storm arrived.

\section{Bioretention}

Bioretention was selected for this study because it is one of the most common GI and has been demonstrated on small-scales in areas of Salt Lake County, in addition to rainwater harvesting. The first step to model bioretention was to quantify the fraction of watershed area occupied under a full bioretention build out scenario. ArcGIS was employed to determine the watershed area feasible for bioretention by quantifying the ripeness of an area, which represents the comparison of land and building value (Nelson, 2009). When the land value exceeds that of the building value the parcel is determined to be ripe. This means that it is due for redevelopment or a major retrofit.

Total acreage due for retrofit was calculated for land directly adjacent to the Jordan River and east of the Jordan River. This is because water that comes from natural streams is primarily from the Wasatch Mountains to the east. The streamflows from the Oquirrh Mountains are much less than from the Wasatch Mountains and water is typically put to beneficial use prior to reaching 
the Jordan River. The acreage was calculated every five years to a maximum of 35 years. The total acreage that could be renovated was added up for the 35 year period below and reduced by $20 \%$. This percentage was the estimate of structures that would be unwilling or unable to perform retrofits or implement GI. Chicago, which strives to be one of the greenest cities in the United States, is requiring that development or redevelopment projects capture the first flush or reduce impervious area by $15 \%$ (Wise, 2008). The $15 \%$ goal was used for this study for Salt Lake City as the amount of future bioretention the city could implement. This equates to 7.3 square kilometers (1,800 acres) of impervious area replaced with bioretention. The study area was approximately 283 square kilometers (70,000 acres), with an estimated 74 square kilometers $(18,200$ acres) of imperviousness. This correlated to approximately $10 \%$ of impervious surface replacement for the $15 \%$ target.

For the modeling of bioretention, the soil characteristics can have a significant impact on how the GI performs. The study area covers a large part of Salt Lake County making site investigations impossible for this study. Therefore, an assumption of soil type was made based on the published soil survey. Salt Lake City and surrounding suburbs were found to be primarily Jordan Sandy Loam (Gardner and Stewart, 1899). Soil characteristics were then specified to represent sandy loam conditions. The important parameters were saturated hydraulic conductivity, average capillary suction and soil moisture deficit. These values were estimated at 12.7 millimeters per hour ( 0.5 inches per hour $), 110$ millimeters ( 0.36 feet) and 79 millimeters ( 0.26 feet), respectively (USEPA, 2010).

\section{Climate Variability}

The Colorado River is a major source of water for a number of states, including Utah. Studies generally have shown a decrease of Colorado River flows in the future, ranging from $10-25 \%$ flow reduction, with an average of 19\% (Nash and Gleick, 1993; Milly et al., 2005; McCabe and Wolock, 2007; Seager et al., 2007). Moreover, comparing Climate Model Intercomparison Project Phase 5 (CMIP5) projections for the period of 2040-2060, to the historical precipitation of 1980-2000 in Salt Lake City, similar results were yielded. Out of 231 projections, about 100 runs of different models and scenarios project reduction of more than $10 \%$ in precipitation. Additionally, 32 projections estimate reduction of more than $15 \%$ and 6 projections estimate reduction of more than $20 \%$ in precipitation. The Jordan River Basin relies heavily on winter precipitation and snowpack, which ultimately supply water to the Jordan River and control the timing of runoff. Additionally, projections indicate that the overall water budget could decrease by $30 \%$ because of increased evapotranspiration and reduced precipitation (UDWR, 2008).

For the purpose of studying the Jordan River and Farmington Bay, scenarios were assigned to have a $20 \%$ reduction in precipitation and natural streamflow. This magnitude of reduction represents a significant, yet reasonable, reduction within the range of projected decreases in streamflow and precipitation. Using a single value at the upper end of the range provides a useful assessment of potential impact that will help to determine the need for more study at lower magnitudes of reduction.

\section{Results}

\section{Jordan River Flows}

The Jordan River is the primary source of inflow to Farmington Bay, accounting for approximately $50 \%$ of the flow. It is also the source of water for the duck clubs of Farmington Bay. The change in flows of the Jordan River will directly affect the reliability of water supply to users and water levels in Farmington Bay. Changes to the Jordan River were computed by finding the average change in flow for each year. That value was then converted to a volume. The averages reported in the results section are the average increase or decrease relative to the baseline or historical scenario for each respective year over a 25 -year simulation. That is to say each year was averaged individually for 25 years and then the average of those was taken and reported. When the average is positive, it means that the difference is greater and therefore more water is lost. The negative values imply water is being gained in the system.

For $15 \%$ replacement of impervious surfaces with bioretention (full bioretention), there was an average reduction in volume from baseline conditions of 5.3 million $\mathrm{m}^{3}$ (4,300 acre-feet) (Fig. 3). This accounts for minimal $(<1 \%)$ reduction of the flow volume for the Jordan River for an average year. The losses occurred primarily at times of high flow, after a precipitation event as the GI effectively reduced the peak flows.

Overall, $100 \%$ RWH actually increased the average daily streamflow by a small amount $(<1 \%)$, which is attributed to the decrease in demand following a storm event in which rain was captured. At this time less water is released from Mountain and Little Dell Reservoirs because user demand is decreased. The average increase of water in little and mountain dell reservoirs was found to be 0.12 million $\mathrm{m}^{3}$ (100 acre-feet) following storm events under $100 \%$ RWH scenarios, with a maximum of 0.58 million $\mathrm{m}^{3}$ (470 acre-feet). In the days following the storm event, less demand for outdoor usage meant increased water bypassing the water treatment plant for that stretch of 
time, which accounts for the increased streamflows in the Jordan River. However, there is still a net loss in some cases to Jordan River flow volume due to the increased loss of surface flow at peak times (Fig. 3). This loss of flow during peak flows trumps the increased water bypassing the Jordan River following the storm event, accounting for the volumetric losses. This water in most cases is destined for the Goggin Drain as the distribution engineer and river commissioner are trying to divert excess water at these times. When the two methods of GI were combined, similar effects were noted. The bioretention tended to reduce the volume, however, when coupled with RWH the volume would increase compared to bioretention only.
Under climate variability conditions $(20 \%$ reduction of inflow and precipitation) there was a reduction in Jordan River flows, as expected. The streamflows showed an average reduction of $11 \%$ from the baseline for each respective year which was less than expected (Fig. 4). Similar to the volumetric values reported, the percentages computed represent taking the average for each year for 25 years and then reporting the average of those values. A reduction of $11 \%$ equates to an average decrease of 49.3 million $\mathrm{m}^{3}$ (40,000 acre-feet) from the baseline condition for $20 \%$ climate variability. The Jordan River saw a maximum reduction of $79 \%$ with respect to daily changes from baseline conditions during the climate variability scenario. These high decreases were especially prevalent during high flows.

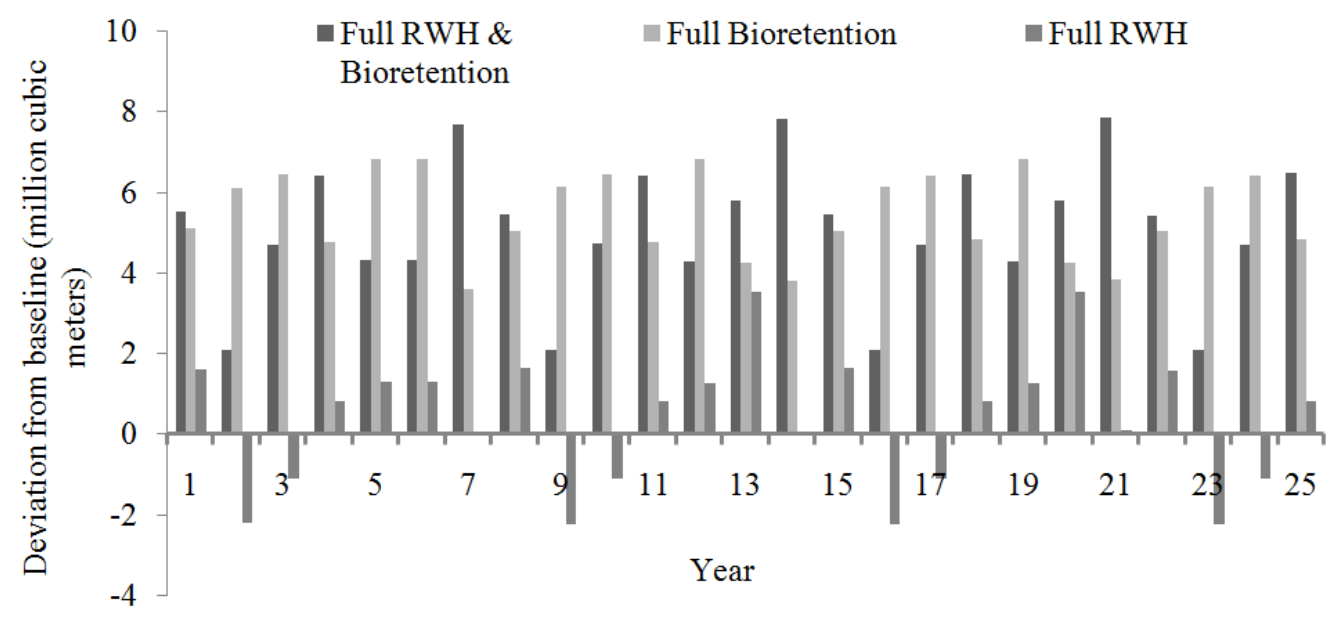

Fig. 3. Change in water volume contributions from Jordan River for bioretention and rainwater harvesting compared to baseline conditions

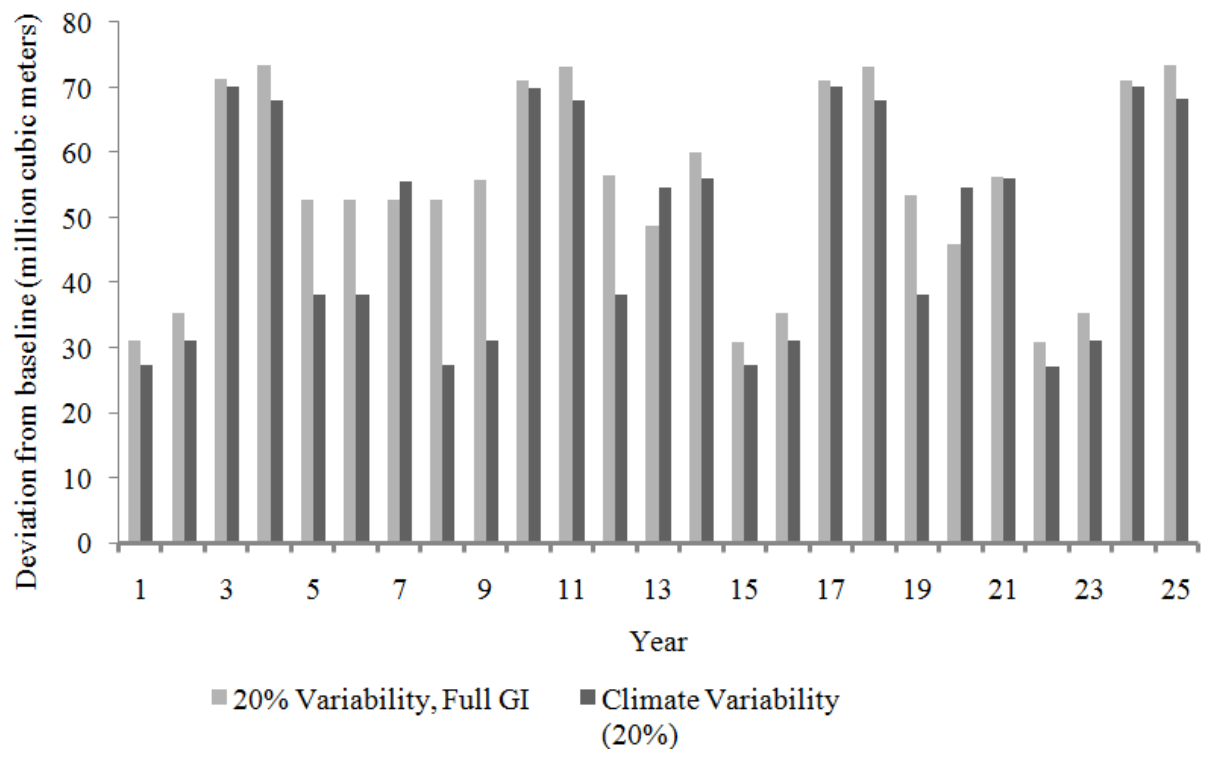

Fig. 4. Graph showing reduction of water (in million cubic meters) from historical conditions to test scenarios 


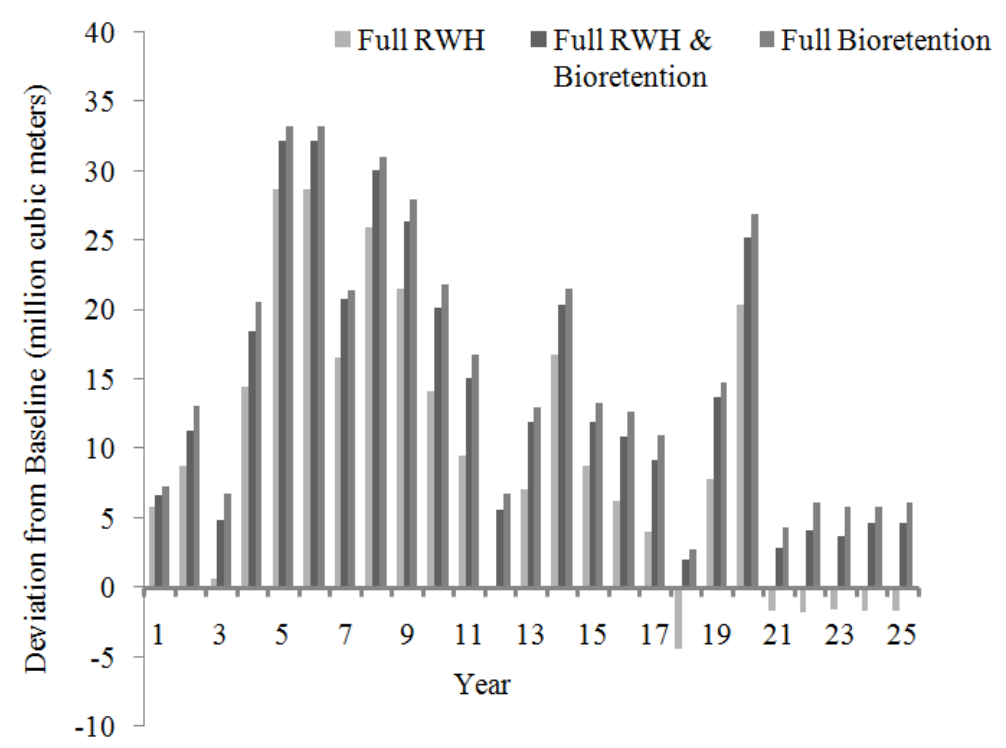

Fig. 5. Farmington Bay average volume increases and decreases for GI scenarios from baseline

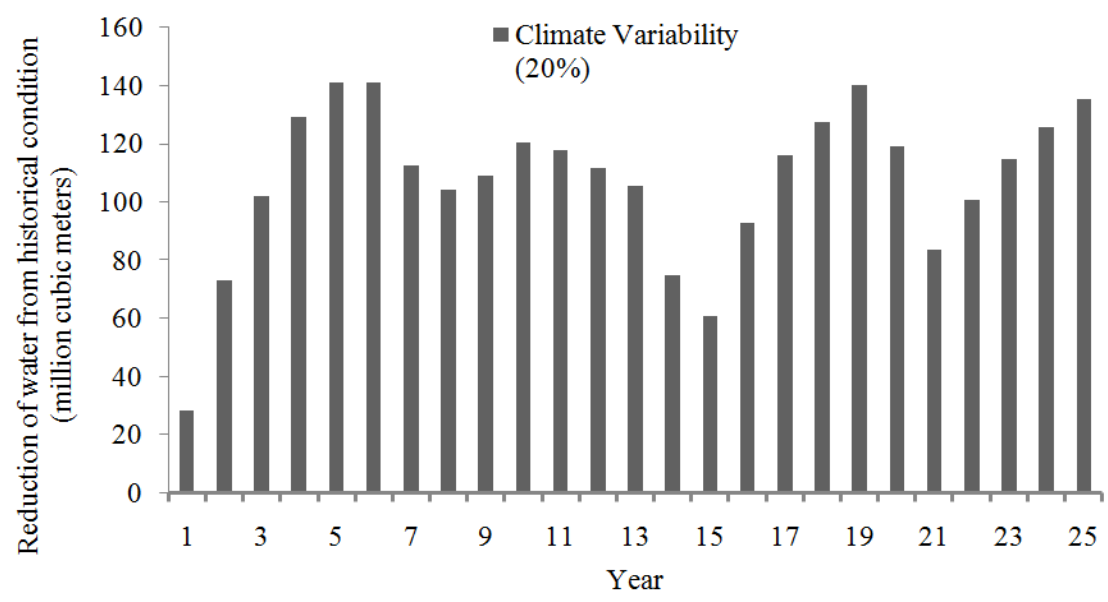

Fig. 6. Graph displaying reduction in Farmington Bay water volume for climate variability scenario compared to historical condition

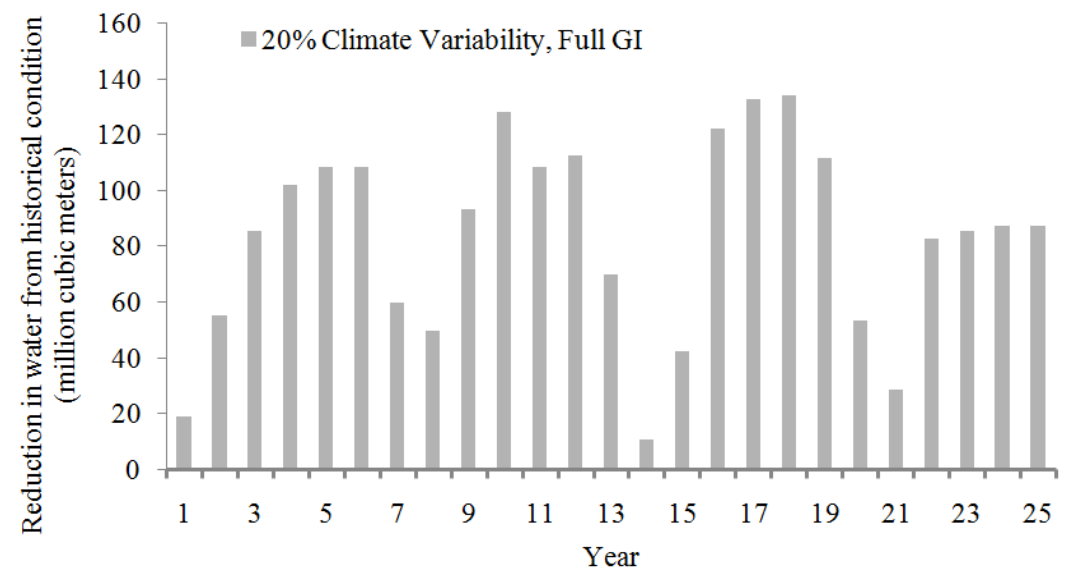

Fig. 7. Graph showing reduction in water volume from climate variability and full GI implementation compared to historical condition 
For the combined scenario with climate variability and full GI $\left(7.3 \mathrm{~km}^{2}\right.$ bioretention implementation and $100 \%$ of homes have a rain barrel) implementation, there is an average annual decrease of streamflow of $12 \%$, which is slightly above that of the climate variability only scenario (Fig. 4).

Considering changes by season, the results for the GI scenarios showed no significant changes with season and type of water year. The changes due to GI occurred directly after storm events regardless of season. Climate variability impacts did show variation in results. Dry years were not affected as much as average and wet years in regards to volume reduction from baseline conditions. The greatest observed decreases from baseline conditions in the Jordan River flows were observed during the years when snowpack and precipitation were the highest. This is because of assumptions made and the way climate variability was modeled, net precipitation losses were most affected at higher precipitation values. The effect of the scenario was to reduce wet years to be similar in magnitude to the baseline average year. Conversely, a dry year only becomes a small amount dryer, which does affect the overall quantity of water. Although small, the change in dry years may be enough to affect the ecosystem and human uses, but these have not been assessed in this study. For the climate variability scenario (20\% reduction of inflow), the effect was more noticeable by season. As noted above for GI, the greatest reductions occurred in the spring when runoff is high and storms are more prevalent. This was followed closely by summer. Fall and winter showed the least deviation from normal.

\section{User Reliability}

After defining how the duck clubs operate and gaining an understanding of their water rights, the reliability of water supply could be evaluated. User reliability was defined by comparing daily flows from selected users (i.e., duck clubs) to flows granted in their water rights. The historical scenario resulted in a reliability of $93 \%$. This is the baseline for comparison with other scenarios. Analyses were performed to determine the user reliability change from RWH and bioretention implementation. Similar to the water flow volume reductions, the two GI scenarios did not cause significant change in user reliability, even when tested together.

Climate variability $(20 \%$ reduction in streamflow and precipitation), on the other hand, did cause a $5 \%$ decrease in user reliability. Combining the GI with the climate variability conditions did not significantly change the results. Interestingly, the results showed an improvement in user reliability with only $4 \%$ decrease in user reliability (compared to the $5 \%$ decrease for the climate variability scenario by itself). Similar to earlier observations, the reason for the improved reliability with GI implementation is attributed to the implementation of rain barrels that leads to a reduced water demand after precipitation events.

Seasonality and the relative wetness of the water year Salt Lake City experienced played a role in how much scenarios impacted user reliability. The greatest decrease from historical conditions due to climate variability was noted in dry years when the water system was already stressed. During wet years the reliability was closer to baseline because there was excess water in the system throughout portions of the year which dampened impacts. Due to the timing of the use of the water associated with the duck clubs, reliability decreased the greatest in the summer and winter periods. This coincides with the period when water is not being pumped from Utah Lake and streamflows in the Jordan River are lower as snowmelt is limited or not occurring. Return flows from water released from Utah Lake for irrigation average out to be approximately 22.2 million $\mathrm{m}^{3}(18,000$ acre-feet) per year, which can decrease flows in the non-growing season by up to $2.83 \mathrm{~m}^{3} / \mathrm{s}$ (100 cfs) (SI and CES, 2009). During this time, the return flows from the wastewater treatment plants are the primary source of reliable flow, providing a base flow for water quality and freeze prevention purposes that can account for up to $25-50 \%$ of water entering the duck clubs.

\section{Farmington Bay Levels}

GI implementation had minimal impacts compared to those caused by climate variability. Of the two, bioretention had the greatest impact on the volume of water reporting to Farmington Bay. The average volumetric loss compared to baseline scenario due to bioretention implementation was 4.6 million $\mathrm{m}^{3}$ (3700 acre-feet) over a 25-year period (Fig. 5). The greatest difference in volume noted for the bioretention implementation was 7.9 million $\mathrm{m}^{3}$ (6,400 acre-feet).

Conversely, in the scenario where each singlefamily home in Murray, Cottonwood Heights, Salt Lake City, Sandy, Millcreek, Midvale and Taylorsville implemented a 757 liters (200 gallon) rain barrel, there was an increase in Farmington Bay volume that reached a maximum of 7.8 million $\mathrm{m}^{3}$ (6300 acre-feet) greater than the baseline scenario. Under the full GI implementation scenario, there was a decrease that averaged out to be 3.2 million $\mathrm{m}^{3}$ (2,600 acre-feet). This is a smaller decrease than was noted with the bioretention scenario only (Fig. 5). The increase from bioretention only was again attributed to rain barrels increasing in stream flows following storm events. Under the RWH and bioretention combined scenario, surface runoff due to stormwater was effectively reduced $25-60 \%$, with smaller storms up to $85 \%$ 
retained from the historical condition. This aligns with Salt Lake County's Stormwater Management Plan, aiding in long-term stormwater management in new and redeveloped areas.

Climate variability had the greatest impact on the water level and volume in Farmington Bay (Fig. 6). The average percent difference between the historical run and climate variability scenario was $36 \%$. This averaged out to be approximately 96.8 million $\mathrm{m}^{3}$ (78,500 acre-feet). Farmington Bay reaches a minimum volume of 50.5 million $\mathrm{m}^{3}(41,000$ acrefeet), $18 \%$ of the initial volume. The largest difference recorded with respect to daily changes from the baseline scenario was $82 \%$.

Finally, the scenario with climate variability and full GI implementation is shown in the (Fig. 7). It shows a decrease across the 25 year simulation. The average decrease was 96.7 million $\mathrm{m}^{3}(80,000$ acrefeet). This is mostly attributed to climate variability as there is a minimal difference between all three scenarios combined compared to just the climate variability alone.

Additional analysis was performed to analyze changes in Farmington Bay across the seasons and by year. Consistent with the Jordan River changes, Farmington Bay saw the greatest volumetric decrease from historical conditions in wet years versus dry years. Dry years were the least affected by climate variability. The largest decrease from historical conditions was noted to occur in the summer, with spring being second largest. The likely reason for this discrepancy is the impact that evapotranspiration has during the summer months on such a water body. In reality, evapotranspiration may not be as high as decreases in water level would lead to higher concentrations of salt and more inflow from the GSL, which is more saline. This saline water is less prone to evaporation; however, the model was not able to account for variations in salinity. It then makes sense to see summer most affected when there are less inflows and higher outflows. Similar to trends noted with Jordan River flows, fall and winter displayed the least variation from historical runs.

Studying impacts to receiving waters due to combined climate variability and GI effects has yet to be conducted in such a manner for Salt Lake City; however, related studies can give additional insight into the results. The Natural Resources Defense Council determined that GI was an effective mitigation strategy to combat climate variability and offset some of its effects (NRDC, 2009). This is determined to be least impactful to the environment of all mitigation strategies (NRDC, 2009). The scenarios that included rain barrels showed an increase in available water, but not enough to mitigate climate variability effects. This study is consistent with the findings of Jensen's (2008) study that showed residential use can be supplemented through RWH in Salt Lake City. In other semi-arid cities, similar results have been found. The city of Tucson, Arizona for example has implemented incentives for rainwater capture to supplement outdoor irrigation. In one specific case, the Nature Conservancy Building put in a cistern that is estimated to save 265,000 liters (70,000 gallons) of water each year at this site alone (LIDWG, 2014). In other studies, RWH had adverse effects on the water budget. In particular, a study performed in the Albemarle-Pamlico River Basins, implementing RWH at $25 \%$ implementation showed a decrease of downstream flow of $6 \%$ (Ghimire and Johnston, 2013). While there are times at which there are decreases shown in the Jordan River-Farmington Bay Model, they are slight accounting for a fraction of a percent of the Jordan River annual volume. There are increases in other areas of the model as well including Mountain Dell and Little Dell Reservoirs that help offset the losses. The Albemarle-Pamlico River Basin resides at a much lower elevation than the Jordan River Basin and has a greater reliance on stormwater for streamflows. In comparison, the Jordan River flows are comprised of less than 7\% stormwater (SI and CES, 2009). This illustrate show GI effects are governed to a significant extent by local conditions.

Bioretention is used to effectively reduce stormwater runoff, thus enhancing water quality and reducing peak flow. From a water supply standpoint, bioretention has been shown to increase evapotranspiration (EPA, 2010a). Conversely, it was found that over time rainwater infiltration through methods such as bioretention can infiltrate enough rainwater to replenish groundwater reserves (Potter, 2000). Additionally, bioretention in the Salt Lake Valley has been shown to increase infiltration rates over preexisting conditions, which could aid in groundwater recharge and increase the water balance (Heiberger, 2013). This study did not model groundwater recharge. The most conservative case in which the water is lost from the budget was employed. In reality, the water retained from GI will be evaporated, transpired, or infiltrated into the ground.

\section{Conclusion}

\section{Analysis Results}

Overall, climate variability posed the greatest threat to negatively impacting the Jordan River streamflow, downstream water users and Farmington Bay water levels. $20 \%$ reduction in precipitation and streamflow due to climate variability decreased the user reliability 
by $5 \%$, which was the greatest decrease noted. This would likely be higher but the duck clubs are unique in that the duck hunting season runs from the end of September to January, which is a time when demands are low. Spreading their demand for water out across the year and at non-peak demand times of year help dampen the effects of climate variability.

Under potential climate variability conditions, Farmington Bay reached a minimum volume of approximately 50.5 million $\mathrm{m}^{3}$ (41,000 acre-feet). At this level, the extent of the mud flats would dominate that of ponded area and could pose threats to Farmington Bay's habitat. An estimated loss of 61 square kilometers $(15,000$ acres) of open bay could result from such losses. This would impact bird nesting, feeding and brine shrimp habitat, among other impacts. At this level, management efforts would be necessary to help maintain water levels and keep water within Farmington Bay. If the water remained at this level for extended periods of time, the mud could turn into fugitive dust and pose a threat to the residents of Davis and Salt Lake County that border Farmington Bay. At such a level the causeway culvert would be restricted to one directional flow to limit water from flowing to the GSL. Another possible decision that could be made would be to weigh the benefits of rerouting the water that goes to the Goggin Drain and utilize existing canals to get the water to Farmington Bay instead of Gilbert Bay. This would keep the freshwater from the Jordan River in Farmington Bay to help recharge the bay as it is reliant on Jordan River's excess flow, whereas the GSL has other primary sources. Additionally, that water could still make its way to the GSL through the Antelope Island Causeway.

GI had minimal impacts to the water budget. The Jordan River and Farmington Bay actually saw increases in average inflow under the RWH scenario, as this caused more water to be kept in the streams. While there was an overall increase to the water balance from RWH scenarios, it was insufficient to offset potential climate variability impacts. At times there were reductions in the water budget due to GI. This was primarily noted during periods of high flow when there was a storm event. In this case, the water is typically being controlled to prevent flooding and the water will report to the Goggin Drain and go unused to the Great Salt Lake. Overall, stormwater comprises a small percentage of the Jordan River budget and therefore poses little to no threat to the water budget but is important for water quality, further making Utah a prime candidate for GI because of the need to control the runoff pollution. Bioretention displayed greater impacts to the Jordan River and Farmington Bay water budget, but not enough to significantly affect water users or the volume in Farmington Bay. The small quantity of water lost from this action is likely trumped by the inherent water quality benefits, increased pervious area and reduced peak flows and flooding potential. Additionally, under these scenarios groundwater recharge was not considered. The volume of water that was shown to decrease from GI would either go to the atmosphere through evapotranspiration or report to the groundwater. Further groundwater modeling capable of modeling different aquifers, variations in gradient and across all soil types could give further insight to groundwater recharge.

Utah laws have become more relaxed related to RWH, but the idea is still not encouraged and incentivized. The results from this paper could help encourage RWH on a larger scale in semi-arid areas worried about reduced return flows. If properly educated, residents could play an important role in supplementing outdoor irrigation with rainwater and decrease the overall water demand. The use of GI aligns with the goal of Salt Lake County's Stormwater Management Plan, providing long-term control in new and redeveloped areas. This will also give increased opportunity for public education of Stormwater impacts, as well as encourage public involvement in maintaining the appearance of the GI. This will provide proactive measures in pollution prevention and help eliminate contaminants flowing to the Jordan River.

\section{Author's Contributions}

Christopher York: Chris was the primary author of this document. He developed the climate variability and green infrastructure scenarios and generated the model results.

Erfan Goharian: He was the primary developer of the model and also aided in editing.

Steven Burian: Guided the design of the research plan, contributed to the writing of the manuscript.

\section{Ethics}

This article is original and contains unpublished material. The corresponding author confirms that all of the other authors have read and approved the manuscript and no ethical issues involved.

\section{References}

Bagley, J.M., R.W. Jeppson and C.H. Milligan, 1964. Water yields in Utah. Utah State University, College of Agriculture and Applied Sciences. 
Barich, J.M., 2014. Sensitivity of stormwater management to spatial scale. MSc Thesis, California Polytechnic State University.

Bishop, C.E., M. Lowe, J. Wallace, R.L. Emerson and J.S. Horn, 2009. Wetlands in the Farmington Bay Area. Utah Geological Survey, Davis County, Utah.

Burian, S.J. and C.A. Pomeroy, 2010. Urban Impacts on the Water Cycle and Potential Green Infrastructure Implications. In: Urban Ecosystems Ecology, Aitkenhead-Peterson, J. and A. Volder (Eds.), American Society of Agronomy, Crop Science Society of America and Soil Science Society of America, ISBN-13: 978-0-89118-181-1, pp: 277-296.

Carter, C.K., 1971. Some ecological considerations of the Farmington Bay estuary and adjacent great salt lake park. University of Utah, Salt Lake City, Utah.

Chadwick, D.G., J.P. Riley, A.J. Seierstad, D.L. Sorensen and N.E. Stauffer, 1986. Expected Effects of In-Lake Dikes on Water Levels and Quality in the Farmington Bay and East Shore Areas of the Great Salt Lake, Utah. 1st Edn., Utah State University, Logan, pp: 17.

Dietz, M.E., 2007. Low impact development practices: A review of current research and recommendations for future directions. Water Air Soil Poll., 186: 351-363. DOI: 10.1007/s11270-007-9484-z

EPA, 2010a. Alternative futures analysis of Farmington Bay wetlands in the great salt lake ecosystem. Office of Research and Development, Environmental Protection Agency, Cincinnati, Ohio.

EPA, 2010b. Green infrastructure in arid and semiarid climates: Adapting innovative stormwater management techniques to the water-limited West. Green Reserve, Environmental Protection Agency.

Gardner, F. and J. Stewart, 1899. A soil survey in the salt lake valley, Utah. Salt Lake City, Utah.

Ghimire, S.R. and J.M. Johnston, 2013. Impacts of domestic and agricultural rainwater harvesting systems on watershed hydrology: A case study in the Albemarle-Pamlico River Basins (USA). Ecohydrol. Hydrobiol., 13: 159-171. DOI: 10.1016/j.ecohyd.2013.03.007

Goharian, E., S. Burian, T. Bardsley and C. Strong, 2015. Incorporating potential severity into vulnerability assessment of water supply systems under climate change conditions. J. Water Resources Plann. Manage.

DOI: 10.1061/(ASCE)WR.1943-5452.0000579

Goharian, E. and S.J. Burian, 2014. Integrated urban water resources modeling in a semi-arid mountainous region using a cyber-infrastructure framework. Proceedings of the 11th International Conference on Hydroinformatics, Aug. 17-21, University of Utah, pp: 1-13.
Heiberger, J., 2013. Infiltration and Potential groundwater recharge performance of stormwater bioretention designed for semiarid climates. MSc Thesis, University of Utah.

Jensen, M.A., 2008. Feasibility of rainwater harvesting for urban water management in Salt Lake City. MSc Thesis, University of Utah, Salt Lake City, Utah.

LIDWG, 2014. Case studies: Low impact green infrastructure. LID Working Group, City of Tuscon, Pima County.

McCabe, G.J. and D.M. Wolock, 2007. Warming may create substantial water supply shortagesin the Colorado River basin. American Geophysical Union.

Milly, P.C.D., K.A. Dunne and A.V. Vecchia, 2005. Global pattern of trends in streamflow and water availability in a changing climate. Nature, 438: 347-350. DOI: 10.1038 /nature04312

Nash, L. and P. Gleick, 1993. The Colorado basin and climate change. EPA, Policy, Planningand Evaluation, EPA Publication.

NRDC, 2009. A clear blue future: How greening California cities can address water resources and climate challenges in the 21 st Century. Technical Report, Natural Resources Defense Council.

Nelson, A.C., 2009. Estimating the ripeness of commercial strips for redevelopment. Practicing Planner. Forthcoming.

Potter, K.W., 2000. Final report: Field evaluation of rain gardens as a method for enhancing groundwater recharge. University of Madison, WI.

SLCWRP/RSC, 2009. Salt Lake Countywide Water Quality Stewardship Plan (WaQSP). Salt Lake County Water Resources Planning and Restoration and Stantec Consulting.

Salt Lake

City. www.watershed.slco.org/wtrQualSteward/

Seager, R., M. Mingfang Ting, I. Held, Y. Kushnir and J. Lu et al., 2007. Model projections of an imminent transition to a more arid climate in South Western North America. Science, 316: 1181-1184.

DOI: $10.1126 /$ science. 1139601

SI and CES, 2009. Jordan River TMDL: Work element 2-pollutant identification and loading. Utah Division of Water Quality.

Steffen, J., J. Mark, C.A. Pomeroy and S.J. Burian, 2013. Water supply and stormwater management benefits of residential rainwater harvesting in U.S. cities. J. Am. Water Resources, 39: 810-815. DOI: $10.1111 /$ jawr. 12038

TT, 2012. North farm creek and dry run tributary implementation plan. Prepared for Environmental Protection Agency, Tetra Tech.

UUHS, 2013. Great Salt Lake microenvironments. University of Utah Health Sciences, Salt Lake City, Utah. 
USEPA, 2010. Stormwater management model user's manual, Version 5.0. Water Supply and Water Resources Division, United States Environmental Protection Agency.

UDWR, 2008. Drought in Utah: Learning from the past-preparing for the future. Utah Division of Water Resources.

Waddell, K.M. and F.K. Fields, 1977. Model for evaluating the effects of dikes on the water and salt balance of Great Salt Lake, Utah. Utah Geological and Mineralogical Survey WaterResources Bulletin.
Walsh, T., C.A. Pomeroy and S.J. Burian, 2014. Hydrologic modeling analysis of a passive, residential rainwater harvesting program in an urbanized, semi-arid watershed. J. Hydrol., 508: 240-253. DOI: 10.1016/j.jhydrol.2013.10.038

Wise, S., 2008. Green infrastructure rising: Best practices in stormwater management. American Planning Association. 